ISSN 1392-3196 / e-ISSN 2335-8947

Zemdirbyste-Agriculture, vol. 104, No. 1 (2017), p. 47-52

DOI 10.13080/z-a.2017.104.007

\title{
Infectivity of Tomato yellow leaf curl virus isolated from imported tomato fruit in Estonia
}

\author{
Kadri JUST ${ }^{1,2}$, Muhammad Naeem SATTAR ${ }^{2,3}$, Usman ARIF ${ }^{2,4}$, Anne LUIK ${ }^{1}$, \\ Anders KVARNHEDEN ${ }^{1,2}$ \\ ${ }^{1}$ Institute of Agricultural and Environmental Sciences, Estonian University of Life Sciences \\ Kreutzwaldi 1, 51014 Tartu, Estonia \\ E-mail: kadri.just@student.emu.ee \\ ${ }^{2}$ Uppsala BioCenter, Swedish University of Agricultural Sciences and Linnean Center of Plant Biology \\ P.O. Box 7080, SE-750 07 Uppsala, Sweden \\ ${ }^{3}$ King Faisal University \\ P.O. Box 420, Al-Ahsaa 31982, Saudi Arabia
}

${ }^{4}$ School of Biotechnology, Royal Institute of Technology (KTH)

SE-106 91, Stockholm, Sweden

\begin{abstract}
There is a risk that Tomato yellow leaf curl virus (TYLCV) and its vector, whiteflies of the Bemisia tabaci species complex, will become established in greenhouses in temperate regions of the world, including northern Europe. In this study, TYLCV isolated from imported tomato fruit in Estonia (originating from Spain) was shown to be able to infect plants of tomato and Nicotiana benthamiana using Agrobacterium-mediated inoculation with an infectious clone as well as using biolistic delivery of products from rolling circle amplification (RCA). A 1.8-mer genomic construct of TYLCV was engineered and efficiently agroinfiltrated into plants of tomato and $N$. benthamiana, and induced symptoms characteristic of natural infection. With Agrobacterium-mediated inoculation, the infection efficiency was $100 \%$ for both tomato and $N$. benthamiana, whereas biolistic inoculation using RCA products resulted in efficiencies of $57 \%$ and $36 \%$, respectively. Particle bombardment with monomeric linear genome failed to produce any infection in tomato or $N$. benthamiana. The genome of TYLCV amplified from tomato fruit was infectious confirming that tomato fruit may serve as a source of virus inoculum. This is the first report of agroinfiltration and particle bombardment assay using TYLCV DNA derived from infected tomato fruit tissue.
\end{abstract}

Key words: agroinfiltration, begomovirus, infectious clone, Solanum lycopersicum, tomato fruit.

\section{Introduction}

Tomato (Solanum lycopersicum L.) is the most important vegetable crop globally and constitutes $72 \%$ of the value of fresh vegetables produced worldwide (Hanssen et al., 2010). The production is affected by many pests and infection of tomato by different viruses, such as Pepino mosaic virus (PepMV; genus Potexvirus, family Alphaflexiviridae) and begomoviruses (genus Begomovirus, family Geminiviridae) may result in significant yield losses. Among the tomato-infecting begomoviruses, Tomato yellow leaf curl virus (TYLCV) has the broadest geographical distribution. From its origin in the Middle East, it has spread throughout the Mediterranean Basin and recently also to Asia, Africa, Australia as well as to North America and South America (Lefeuvre et al., 2010; EFSA PLH, 2014). Symptoms induced by TYLCV include upward curling and yellowing of leaves, stunting of the plant, flower abortion and infection can cause up to $100 \%$ yield loss. TYLCV has a genome of circular single-stranded (ss)DNA and it is transmitted in a persistent manner by whiteflies of the Bemisia tabaci species complex (Navas-Castillo et al., 2011). The rapid global spread of TYLCV is the result of international movement of virus-infected plant material and of plants (including non-hosts of TYLCV) harbouring viruliferous whiteflies (EFSA PLH, 2014). Recently, TYLCV has also been reported to be seed transmitted with high seed transmission rates from infected tomato plants (Kil et al., 2016).

In southern Europe, B. tabaci and TYLCV have become established along the Mediterranean coastal regions, while the outdoor conditions in other parts of Europe are unfavourable for its spread and establishment. 
However, outbreaks of $B$. tabaci and viruses it transmits can nevertheless occur under greenhouse cultivation conditions (Botermans et al., 2009; EFSA PLH, 2013). The present increase in international travel and trade in plant material enables dissemination of the insect vector and associated viruses to greenhouses in northern Europe, including those in regions with protected zone status. For instance, Sweden, Finland, Republic of Ireland and the United Kingdom are officially free of $B$. tabaci (EFSA PLH, 2013), but it is frequently intercepted also in these areas (Cuthbertson et al., 2011; EPPO, 2012). In Lithuania, B. tabaci has been detected on ornamental plants in greenhouses (Ivinskis et al., 2009) and in Estonia on imported poinsettia (Euphorbia pulcherimma) plants (Estonian Agricultural Board, 2005).

Also traded tomato fruit may play a role in spread of whiteflies and associated viruses (Wege, 2007). B. tabaci can be carried on leaves of vine tomatoes as well as on sepals and peduncles, while TYLCV-infected tomato fruit may act as a source for virus transmission by whiteflies (Delatte et al., 2003; EFSA PLH, 2013). Considering the widespread presence of TYLCV in tomato-production areas in southern Europe, it is expected that virus is spread to northern Europe by international trade via infected plant material and insect vector. In tests of tomato fruit imported from the Mediterranean Region to Estonia and Sweden, $28 \%$ and $10 \%$ of the fruit were infected with TYLCV, respectively (Just et al., 2014). The aim of this project was to test the infectivity of TYLCV DNA found in imported tomato fruit in Estonia. In northern Europe, B. tabaci is a quarantine pest and vector transmission tests of TYLCV and other begomoviruses are therefore complicated to carry out. Thus, alternative biotechnological methods such as agroinfiltration and biolistic inoculation were selected. Experiments showed that TYLCV isolated from imported tomato fruit is infectious and able to induce symptoms in tomato plants.

\section{Materials and methods}

Construction of an infectious clone for Tomato yellow leaf curl virus (TYLCV). Imported tomato fruits were previously used for isolation of TYLCV fulllength genomes and isolate TYLCV-[EE-Imp-05-08] (accession No. HF548826) was selected for construction of an infectious clone. During cloning, the 1.0-mer clone was named pGTYEE-1.0 (Just et al., 2014). Experiments were carried out at the Swedish University of Agricultural Sciences and Estonian University of Life Sciences in 2010-2013. The 0.8-mer clone containing the replication origin was released from pGTYEE-1.0 by digestion with $\mathrm{SaCI}$ and $\mathrm{NcoI}$. The resulting fragment was cloned into SacI and NcoI digested pLH7000*, which is a modified form of the binary vector pLH7000, and the resulting clone was named pLTY-0.8. The constructs pGTYEE-1.0 and pLTY-0.8 were digested with $S a c$ I to release the fulllength genome and linearize pLTY-0.8, respectively. The full-length genome was ligated into the linearized pLTY0.8 , resulting in a 1.8 -mer construct of the virus genome named pLTY-1.8.
Agrobacterium transformation and inoculation of full-length clone. The partial dimer construct pLTY-1.8 was transformed into cells of Agrobacterium tumefaciens strain C58C1 using freeze-thaw transformation (Weigel, Glazebrook, 2006). Polymerase chain reaction (PCR) was run to confirm the presence of begomovirus DNA in agrobacteria as described previously (Leke et al., 2012; Just et al., 2014). Subsequently, $5 \mathrm{ml}$ of culture was used to inoculate $50 \mathrm{ml}$ of Luria-Bertani (LB) containing respective antibiotics, $10 \mathrm{mM}$ 2-(N-morpholino) ethanesulfonic acid (MES) and $150 \mu \mathrm{M}$ acetosyringone, and the culture was incubated overnight with shaking $\left(28^{\circ} \mathrm{C}, 250 \mathrm{rpm}\right)$. Bacteria were harvested by centrifugation at $8000 \mathrm{rpm}$ for $15 \mathrm{~min}$ and the pellet was resuspended in $20 \mathrm{ml}$ buffer $\left(10 \mathrm{mM} \mathrm{MgCl}_{2}, 10 \mathrm{mM}\right.$ MES and $150 \mu \mathrm{M}$ acetosyringone). The optical density of inoculum was 0.6. Leaves of tomato (Solanum lycopersicum L.) cv. 'Moneymaker' and Nicotiana benthamiana were infiltrated on the lower side with a $2 \mathrm{ml}$ syringe without a needle. For both tomato and $N$. benthamiana, 14 plants were inoculated at two-leaf stage. One negative control plant was inoculated both for tomato and $N$. benthamiana with A. tumefaciens harbouring the empty binary vector pLH7000*. Plants were maintained in a climate chamber at $23^{\circ} \mathrm{C}$ with a photoperiod of $16 / 8 \mathrm{~h}$ light/dark and monitored for symptom development. The plants were tested for viral infection by PCR one month after inoculation.

Inoculation of full-length clone by biolistic delivery. Plants of $N$. benthamiana and S. lycopersicum cv. 'Moneymaker' were bombarded at two-leaf stage by a particle inflow system gene gun (Clapham et al., 2000) with two types of inoculum: linear genome monomer of the isolate TYLCV-[EE-Imp-05-08] released from the clone pGTYEE-1.0 by restriction with $\mathrm{SacI}$, and rolling circle amplification (RCA) product of religated (circular) genome monomer released from pGTYEE-1.0. Viral DNA $\left(1 \mu \mathrm{g}\right.$ plant $\left.^{-1}\right)$ was coated onto gold particles and the pellet was finally re-suspended in $100 \%$ ethanol. An aliquot $\left(20 \mu\right.$ plant $\left.^{-1}\right)$ was deposited on a metal sieve plate and used for bombardment. A partial vacuum of $\sim 7.5 \mathrm{~cm} \mathrm{Hg}$ was applied by means of a vacuum ejector and the particles were accelerated by releasing a millisecond of pressurized helium (5.8 bar) using a solenoid valve. For each set of inoculations, 14 plants each of tomato and $N$. benthamiana at two-leaf stage were used. As a negative control, one plant for each species was mock-inoculated with gold particles alone. Following inoculation, plants were kept in a growth chamber at $23^{\circ} \mathrm{C}$ with a photoperiod of $16 / 8 \mathrm{~h}$ light/dark and monitored for symptom development. The plants were tested for viral infection by PCR one month after inoculation. Data was statistically analysed using a Chisquare test for independence with $\alpha$ value 0.05 .

Confirmation of infection by PCR. Plant DNA was extracted from a young systemic leaf of inoculated plants by homogenization of tissue in an alkaline solution $(0.5 \mathrm{~N} \mathrm{NaOH})$ followed by neutralization in $100 \mathrm{mM}$ TrisHCl pH 8.0. A fragment from the $C P$ gene of TYLCV (579 bp) was amplified by PCR as described previously (Leke et al., 2012; Just et al., 2014). 
Southern blot hybridization. Total DNA was extracted (Weigel, Glazebrook, 2009) from young systemic leaves of plants, which had been inoculated with TYLCV-[EE-Imp-05-08] by either agroinfiltration (three plants each of tomato and $N$. benthamiana) or biolistic delivery (two plants each of tomato and $N$. benthamiana) and that had tested virus positive by PCR as well as from negative control plants. For Southern blot analysis, both undigested DNA and DNA restricted with NdeI were included. NdeI has a unique restriction site in the genome of TYLCV-[EE-Imp-05-08]. The DNA was separated by electrophoresis in a $1.2 \%$ agarose gel in $1 \%$ Tris-acetateEDTA(TAE) buffer. After an initial depurination in $0.25 \mathrm{M}$ $\mathrm{HCl}$ for $10 \mathrm{~min}$, the gel was rinsed in deionized $\mathrm{H}_{2} \mathrm{O}$ and consecutively soaked in a denaturation solution $(0.4 \mathrm{M}$ $\mathrm{NaOH}$ ) for 30 min. DNA was transferred to Hybond ${ }^{\mathrm{TM}}$ XL membranes (GE Healthcare, UK) by capillary force, and the membrane was washed in $2 \times$ saline-sodium citrate (SSC) buffer to remove any gel traces and subsequently dried. DNA was fixed to the membranes using a Stratagene
UV crosslinker (Artisan Technology Group, USA) . The membrane was hybridized with a PCR product for the $C P$ gene of TYLCV-[EE-Imp-05-08] radioactively labelled with $\alpha{ }^{32} \mathrm{P}$ using Rediprime II DNA Labeling System (GE Healthcare, UK). Hybridization was performed at $65^{\circ} \mathrm{C}$ for 16 hours. The membrane was washed once with $2 \times$ $\mathrm{SSC} / 1 \% \mathrm{SDS}$ and once with $2 \times \mathrm{SSC} / 0.1 \% \mathrm{SDS}$ at $65^{\circ} \mathrm{C}$, wrapped in plastic, exposed to white-screens and the signal was detected using a phosphoimager (Bio-Rad, USA).

\section{Results}

Symptom appearance and analysis of viral DNA in agroinfiltrated plants. A genomic 1.8-mer construct of TYLCV-[EE-Imp-05-08] successfully infected plants of $S$. lycopersicum and $N$. benthamiana by agroinfiltration and induced symptoms resembling natural infection: leaf curling and distortion, yellowing of leaves and reduction in plant growth (Fig. $1 \mathrm{~A}, \mathrm{D}, \mathrm{F}$ ).
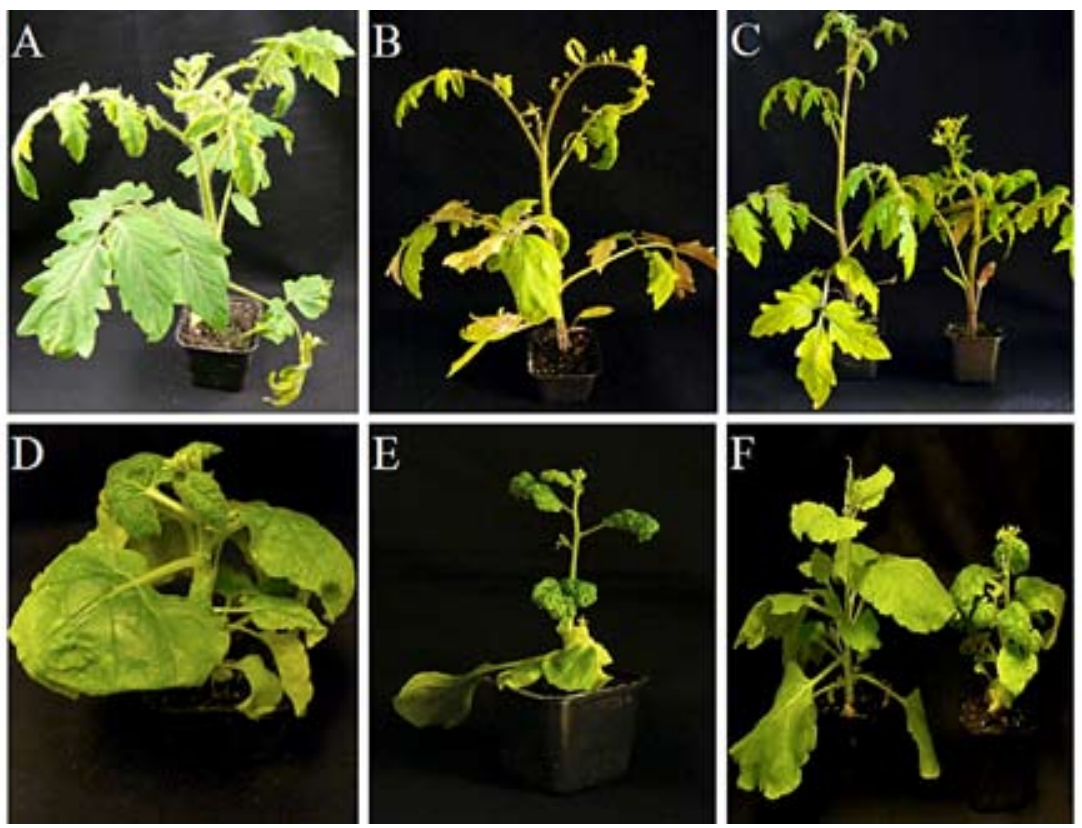

$\mathrm{C}$ - mock-inoculated tomato $v$ s biolistic delivery of rolling circle amplification (RCA) product, $\mathrm{F}$ - mock-inoculated $N$. benthamiana $v s$ agroinfiltration

Figure 1. Representative infection symptoms on plants of tomato (A, B, C) and Nicotiana benthamiana (D, E, F) 40 days after inoculation by TYLCV-[EE-Imp-05-08], either inoculated using an infectious clone and Agrobacterium tumefaciens (A, D, F) or biolistic delivery of circular genome monomer $(\mathrm{B}, \mathrm{C}, \mathrm{E})$

The first symptoms appeared 2-4 weeks after inoculation and one month after inoculation, all 14 plants of both tomato and $N$. benthamiana were positive for
TYLCV infection when tested by PCR (Table). Neither viral DNA nor symptoms of infection were observed in plants inoculated with Agrobacterium containing empty

Table. Results of agroinfiltration and gene gun bombardment of tomato and Nicotiana benthamiana with TYLCV[EE-Imp-05-08]

\begin{tabular}{|c|c|c|c|}
\hline & \multicolumn{3}{|c|}{ No. of plants infected / No. of plants inoculated / Inoculation efficiency (\%) } \\
\hline & Agroinfection & Gene gun & Gene gun \\
\hline Host plant & & RCA product & linear monomer \\
\hline Tomato & $14 / 14 / 100 \%$ & $8 / 14 / 57 \%$ & $0 / 14 / 0 \%$ \\
\hline N. benthamiana & $14 / 14 / 100 \%$ & $5 / 14 / 36 \%$ & $0 / 14 / 0 \%$ \\
\hline
\end{tabular}

RCA - rolling circle amplification 
binary vector. With an inoculation efficiency of $100 \%$, the cloned viral DNA represented a fully biologically active copy of the genome of the TYLCV isolate detected from imported tomato fruit.

Analysis of viral DNA in plants inoculated by biolistic delivery. Tomato and $N$. benthamiana plants inoculated with RCA product of TYLCV-[EE-Imp-05-08] started to display typical symptoms of TYLCV infection 2-3 weeks after inoculation (Fig. 1 B, C, E). The mock-inoculated plants used as negative control did not show any symptoms. Out of $14 \mathrm{~N}$. benthamiana plants and 14 tomato plants inoculated with the RCA product, 5 and 8 plants were symptomatic, respectively (Table). Infection was confirmed by PCR one month after inoculation. The inoculation efficiency of RCA product by particle bombardment was $57 \%$ and $36 \%$ for tomato and $N$. benthamiana, respectively. The null hypothesis for a Chi-squared test for independence stated that there is no statistical relationship between species and infectivity. Since the calculated Chi-square value (1.29) was lower than the critical value (3.84) and the probability value $(0.26)$ was higher than the alpha value (0.05), the null hypothesis could not be rejected. After particle bombardment with the linear genome monomer of TYLCV-[EE-Imp-05-08] released from the clone pGTYEE-1, none of the 14 plants of tomato or 14 plants of $N$. benthamiana became infected.

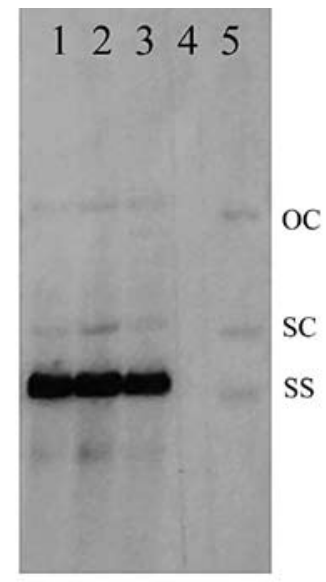

Notes. The plants were sampled at 45 days after inoculation. Each lane represents an individual plant. The positions of open circle (oc) and supercoiled (sc) forms of double-stranded viral DNA are indicated as well as viral single-stranded DNA (ss).

Figure 2. Southern blot analysis of total DNA extracted from tomato plants inoculated with TYLCV-[EEImp-05-08] using agroinfiltration (lanes 1-3) and biolistics (lane 5) or agroinfiltrated with empty binary vector (lane 4)

Confirmation of infectivity by Southern blot hybridization. Accumulation of genomic ssDNA of TYLCV and its replicative forms (open circular and supercoiled dsDNA) in systemic leaves of agroinfiltrated and bombarded plants was verified by Southern blot analysis of plants sampled at 45 days after inoculation both for tomato (Fig. 2) and N. benthamiana (not shown).
As expected, restriction digest with $N d e$ I, which cuts once in the genome of TYLCV-[EE-Imp-05-08], resulted in a linearization of the dsDNA forms (results not shown). No probe hybridization occurred for negative controls.

\section{Discussion}

Infectivity of an Estonian TYLCV isolate from imported tomato fruit was demonstrated using agroinfiltration and biolistic inoculation. Agroinoculation has been an important technique for viral inoculation studies since the mid-1980s (Vaghchhipawala, Mysore, 2008), and it has successfully been used to inoculate tomato plants with cloned tandem repeats of TYLCV DNA derived from leaf tissues (Lapidot et al., 2007). Agroinoculation with the infectious 1.8-mer construct of TYLCV-[EE-Imp-05-08] amplified from tomato fruit resulted in an infectivity of $100 \%$ and the development of TYLCV symptoms both on tomato and $N$. benthamiana plants. In addition, plants of tomato and $N$. benthamiana were bombarded with RCA product and infectivity of 57\% and $36 \%$ was obtained, respectively. The first successful biolistic inoculation of TYLCV was done by Morilla et al. (2005) using dimeric forms of DNA of TYLCV derived from pepper leaf tissue. Similar inoculation efficiencies were obtained as in the current study: $50 \%$ and $75 \%$ on tomato and $N$. benthamiana, respectively. Lapidot et al. (2007) bombarded tomato with circular full-length DNA of TYLCV with an inoculation efficiency of $37 \%$. They also demonstrated infection after bombardment of Datura stramonium plants with a linear monomer of the TYLCV genome. However, none of the inoculated plants of tomato or $N$. benthamiana in the current study became infected after bombardment with a linear TYLCV genome monomer.

Current inoculation experiments show that infectious TYLCV is present in imported fruit in northern Europe and that it poses a potential virus source for transmission if the insect vector is introduced. In 2007, infection of TYLCV was recorded in 19 tomato greenhouse production sites in the Netherlands. The outbreak was probably the result of a single introduction of the virus, and introduced vector accounted for local spread (Botermans et al., 2009). Another example of an infectious virus detected in imported tomato fruit is PepMV in Lithuania (Staniulis et al., 2012). Using mechanical transmission, it was shown that PepMV from imported tomato fruit could be transmitted to tomato and several other host plants. In surveys of Lithuania, PepMV was also detected in tomato samples from commercial greenhouses (Staniulis et al., 2012; Šneideris et al., 2013). PepMV has rapidly spread throughout Europe and dissemination by infected fruit is a possible way (Hanssen et al., 2010). Thus, fruit and vegetables represent a virus dissemination pathway that is currently largely unregulated. Although many inoculation assays on TYLCV have been performed using DNA derived from leaf tissues, this is the first report of agroinfiltration and particle bombardment assay using TYLCV DNA 
derived from infected tomato fruit. To conclude, tomato fruit can act as a pathway of entry for TYLCV, which has to be considered.

\section{Conclusions}

1. DNA of Tomato yellow leaf curl virus (TYLCV) amplified from imported tomato fruit was infective, confirming that tomato fruit may serve as a source of virus inoculum.

2. Agroinfiltration and gene gun bombardment with rolling circle amplification (RCA) product of circular genome monomer resulted in symptoms resembling those of natural infection.

3. Presence of genomic ssDNA of TYLCV and its replicative open circular and supercoiled dsDNA forms in inoculated plants was confirmed by Southern blot hybridization.

\section{Acknowledgements}

The authors wish to thank Eve Aruvee for her guidance with statistical analysis, and Nina Lukhovitskaya for providing binary vector pLH7000* and advice. This research was supported by European Social Fund's Doctoral Studies and Internationalisation Programme DoRa, Archimedes Foundation and by institutional research funding IUT36-2 of the Estonian Ministry of Education and Research. U. Arif and M. N. Sattar were supported by the HEC (Higher Education Commission) and Swedish Institute under the program "Overseas Scholarship Scheme for PhD in Selected Fields".

Received 06072016 Accepted 11112016

\section{References}

Botermans M., Verhoeven J. T. J., Jansen C. C. C., Roenhorst J. W., Stijger C. C. M. M., Pham K. T. K. 2009. First report of Tomato yellow leaf curl virus in tomato in the Netherlands. Plant Disease, 93 (10): 1073 https://doi.org/10.1094/PDIS-93-10-1073C

Clapham D., Elfstrand M., Sabala I., Von Arnold S., Demel P., Koop H. U. 2000. Gene transfer by particle bombardment to embryogenic cultures of Picea abies and the production of transgenic plantlets. Scandinavian Journal of Forest Research, 15 (2): 151-160 https://doi.org/10.1080/028275800750014957

CuthbertsonA. G. S., Blackburn L. F., Eyre D. P., Cannon R. J. C., Miller J., Northing P. 2011. Bemisia tabaci: The current situation in the UK and the prospect of developing strategies for eradication using entomopathogens. Insect Science, 18 (1): 1-10 https://doi.org/10.1111/j.1744-7917.2010.01383.x

Delatte H., Dalmon A., Rist D., Soustrade I., Wuster G., Lett J. M., Goldbach R. W., Peterschmitt M., Reynaud B. 2003. Tomato yellow leaf curl virus can be acquired and transmitted by Bemisia tabaci (Gennadius) from tomato fruit. Plant Disease, 87 (11): 1297-1300 https://doi.org/10.1094/PDIS.2003.87.11.1297
EFSA Panel on Plant Health (PLH). 2013. Scientific opinion on the risks to plant health posed by Bemisia tabaci species complex and viruses it transmits for the EU territory. EFSA Journal, 11 (4): 3162 https://doi.org/10.2903/j.efsa.2013.3162

EFSA Panel on Plant Health (PLH). 2014. Scientific opinion on the pest categorisation of Tomato yellow leaf curl virus and related viruses causing tomato yellow leaf curl disease in Europe. EFSA Journal, 12 (10): 3850 https://doi.org/10.2903/j.efsa.2014.3850

EPPO. 2012. EPPO Technical Document No. 1061: EPPO study on the risk of imports of plants for planting. EPPO Paris. www.eppo.int/QUARANTINE/EPPO_Study_on_ Plants_for_planting.pdf

Estonian Agricultural Board. 2005. www.pma.agri.ee/ download.php?getfile2 $=3062$

Hanssen I. M., Lapidot M., Thomma B. P. H. J. 2010. Emerging viral diseases of tomato crops. Molecular Plant-Microbe Interactions, 23 (5): 539-548 https://doi.org/10.1094/MPMI-23-5-0539

Ivinskis P., Rimšaitė J., Ostrauskas H., Taluntytė L. 2009. Alien insects and spider species and species spreading naturally in Lithuania. $5^{\text {th }}$ international conference Knowledgebased Technologies and OR Methodologies for Strategic Decisions of Sustainable Development. Vilnius, Lithuania, p. $451-455$

Just K., Leke W. N., Sattar M. N., Luik A., Kvarnheden A. 2014. Detection of Tomato yellow leaf curl virus in imported tomato fruit in northern Europe. Plant Pathology, 63 (6): 1454-1460 https://doi.org/10.1111/ppa.12205

Kil E. J., Kim S., Lee Y. J., Byun H. S., Park J., Seo H., Kim C. S., Shim J. K., Lee J. H., Kim J. K., Lee K. Y., Choi H. S., Lee S. 2016. Tomato yellow leaf curl virus (TYLCV-IL): a seed-transmissible geminivirus in tomatoes. Scientific Reports, 6: 19013 https://doi.org/10.1038/srep19013

Lapidot M., Weil G., Cohen L., Segev L., Gaba V. 2007. Biolistic inoculation of plants with Tomato yellow leaf curl virus DNA. Journal of Virological Methods, 144 (1-2): 143-148 https://doi.org/10.1016/j.jviromet.2007.04.011

Lefeuvre P., Martin D. P., Harkins G., Lemey P., Gray A. J. A., Meredith S., Lakay F., Monjane A., Lett J. M., Varsani A., Heydarnejad J. 2010. The spread of Tomato yellow leaf curl virus from the Middle East to the world. PLoS Pathogens, 6 (10): e1001164 https://doi.org/10.1371/journal.ppat.1001164

Leke W. N., Brown J. K., Ligthart M. E., Sattar M. N., Njualem D. K., Kvarnheden A. 2012. Ageratum conyzoides: a host to a unique begomovirus disease complex in Cameroon. Virus Research, 163 (1): 229-237 https://doi.org/10.1016/j.virusres.2011.09.039

Morilla G., Janssen D., García-Andrés S., Moriones E., Cuadrado I. M., Bejarano E. R. 2005. Pepper (Capsicum annuum) is a dead-end host for Tomato yellow leaf curl virus. Phytopathology, 95 (9): 1089-1097 https://doi.org/10.1094/PHYTO-95-1089

Navas-Castillo J., Fiallo-Olivé E., Sánchez-Campos S. 2011. Emerging virus diseases transmitted by whiteflies. Annual Review of Phytopathology, 49: 219-248 https://doi.org/10.1146/annurev-phyto-072910-095235

Staniulis J., Zitikaitė I., Žižytė M., Jackevičienė E., Urbanavičienè L., Šneideris D. 2012. Detection and molecular identification of alien viruses of plums, sugar beets and tomatoes. Zemdirbyste-Agriculture, 99 (1): 85-92 
Šneideris D., Žižytė M., Zitikaite I., Urbanavičienė L., Staniulis J. 2013. First report of two distinct strains of Pepino mosaic virus infecting tomatoes in greenhouses in Lithuania. Journal of Plant Pathology, 95 (1): 217

Vaghchhipawala Z. E., Mysore K. S. 2008. Agroinoculation: a simple procedure for systemic infection of plants with viruses. Methods in Molecular Biology, 451: 555-562 https://doi.org/10.1007/978-1-59745-102-4_38

Wege C. 2007. Movement and localization of tomato yellow leaf curl viruses in the infected plant. Czosnek H. (ed.). Tomato yellow leaf curl virus disease. Dordrecht, the Netherlands, p. 185-206

https://doi.org/10.1007/978-1-4020-4769-5_11
Weigel D., Glazebrook J. 2006. Transformation of agrobacterium using the freeze-thaw method. Cold Spring Harbor Protocols https://doi.org/10.1101/pdb.prot4666

Weigel D., Glazebrook J. 2009. Dellaporta miniprep for plant DNA isolation. Cold Spring Harbor Protocols https://doi.org/10.1101/pdb.prot5178

ISSN 1392-3196 / e-ISSN 2335-8947

Zemdirbyste-Agriculture, vol. 104, No. 1 (2017), p. 47-52

DOI 10.13080/z-a.2017.104.007

\title{
Pomidorų lapų geltonosios garbanès viruso, izoliuoto iš į Estiją ịvežtų pomidorų vaisių, infektyvumas
}

\author{
K. Just ${ }^{1,2}$, M. N. Sattar ${ }^{2,3}$, U. Arif ${ }^{2,4}$, A. Luik ${ }^{1}$, A. Kvarnheden ${ }^{1,2}$ \\ ${ }^{1}$ Estijos gyvybės mokslų universiteto Žemės ūkio ir aplinkos mokslų institutas \\ ${ }^{2}$ Švedijos žemès ūkio universiteto ir Linejjaus augalų biologijos centro Upsalos biocentras \\ ${ }^{3}$ Saudo Arabijos Karaliaus Faisal universitetas \\ ${ }^{4}$ Švedijos Karališkojo technologijos instituto Biotechnologijos mokykla
}

\section{Santrauka}

Yra pavojus, kad pomidoru mozaikos geltonasis (garbanojimosi) virusas (TYLCV) ir jo pernešejas baltosios Bemisia tabaci rūšies komplekso muselès paplis šiltnamiuose pasaulio vidutinio klimato regionuose, taip pat ir Europos šiaurinèje dalyje. Tyrimo metu buvo nustatyta, kad TYLCV, izoliuotas iš į Estiją ịvežtų (ispaniškos kilmès) pomidorų vaisių, galejo infekuoti pomidorų ir Nicotiana benthamiana augalus juos inokuliuojant Agrobacterium klonu su viruso genomu ir bolistiniu metodu įvedant viruso genomo riedančio rato amplifikacijos produktus. Parengtas konstruktas su TYLCV genomu buvo efektyviai transformuotas i pomidoro bei $N$. benthamiana augalus ir sukèlè natūraliai infekcijai būdingus simptomus. Inokuliuojant su Agrobacterium, infekcijos efektyvumas pomidorams ir $N$. benthamiana buvo $100 \%$, o biolistinio inokuliavimo naudojant riedančio rato amplifikacijos produktus efektyvumas buvo atitinkamai 57 ir $36 \%$. Bombarduojant dalelemis, padengtomis linijiniu viruso genomu nepavyko sukelti infekcijos nei pomidoruose, nei $N$. benthamiana. Iš pomidorų vaisių amplifikuotas TYLCV genomas gebejjo užkrèsti augalus, ir tai patvirtino prielaidą, kad pomidorų vaisiai gali būti viruso užkrato šaltinis. Śiame straipsnyje pirmą kartą pranešama apie agroinfiltravimo ir bombardavimo dalelèmis tyrimą naudojant TYLCV DNR, išskirtą iš užkrèstų pomidorų audinių.

Reikšminiai žodžiai: agroinfiltracija, begomovirusas, infekcinis klonas, pomidorų vaisiai, Solanum lycopersicum. 